\title{
International Union of Basic and Clinical Pharmacology. LXXVIII. Lysophospholipid Receptor Nomenclature
}

\author{
Jerold Chun, Timothy Hla, Kevin R. Lynch, Sarah Spiegel, and Wouter H. Moolenaar
}

Department of Molecular Biology, Dorris Neuroscience Center, the Scripps Research Institute, La Jolla, California (J.C.); Center for Vascular Biology, Department of Pathology and Laboratory Medicine, Weill Medical College of Cornell University, New York, New York (T.H.); Department of Pharmacology, University of Virginia, Charlottesville, Virginia (K.R.L.); Department of Biochemistry and Molecular Biology, Virginia Commonwealth University School of Medicine, Richmond, Virginia (S.S.); and Division of Cell Biology, the Netherlands Cancer Institute, Amsterdam, the Netherlands (W.H.M.)

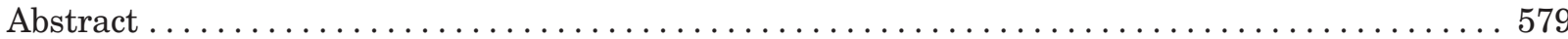

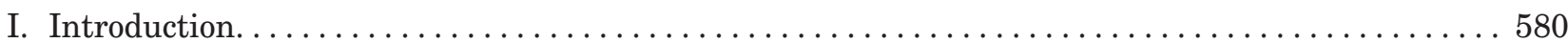

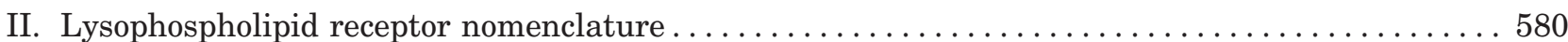

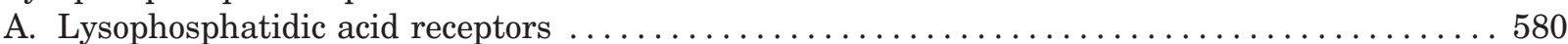

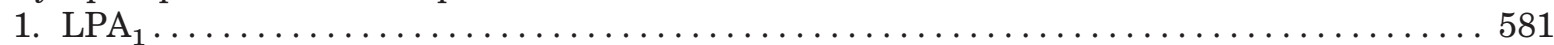

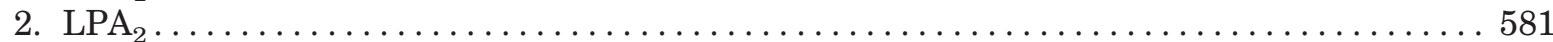

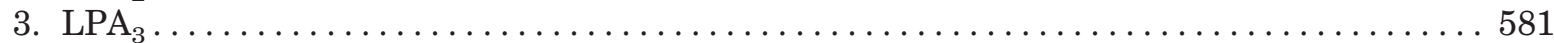

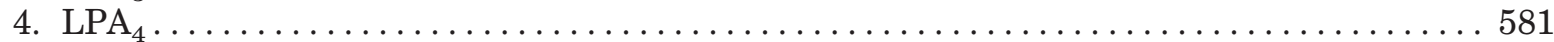

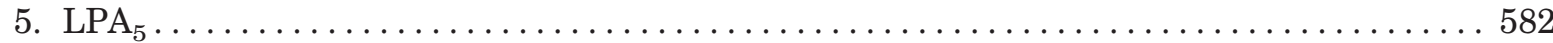

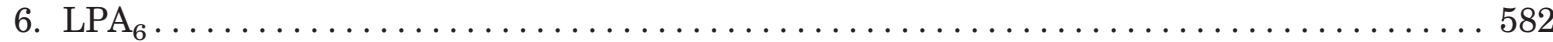

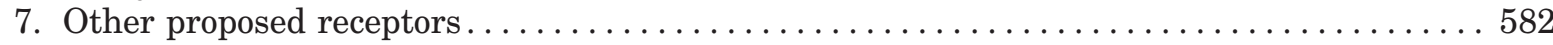

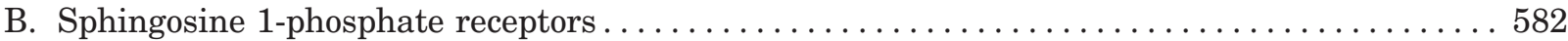

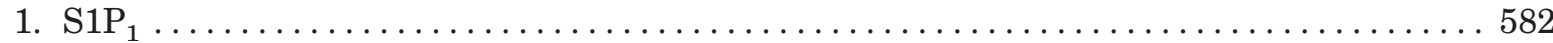

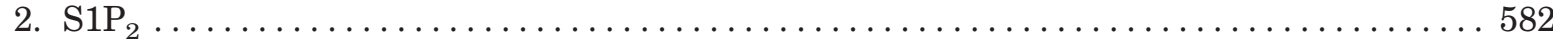

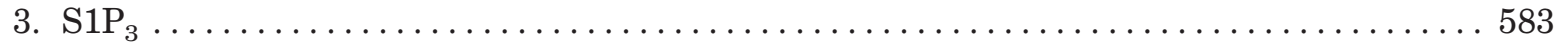

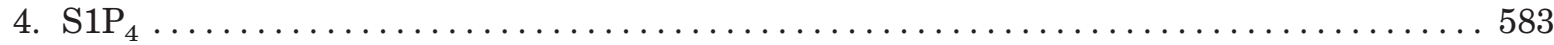

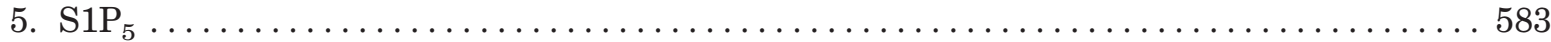

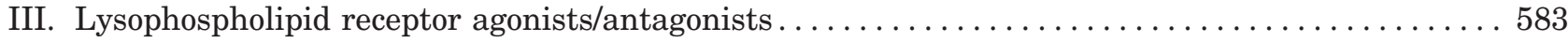

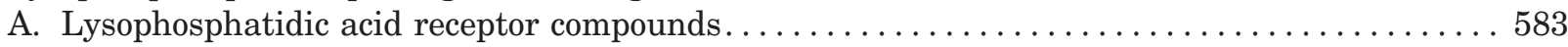

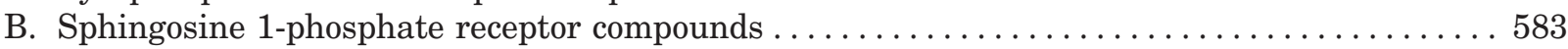

C. Biological functions of lysophosphatidic acid

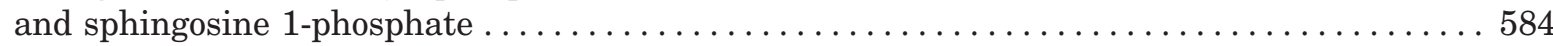

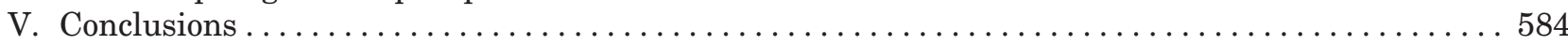

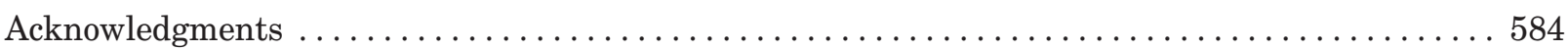

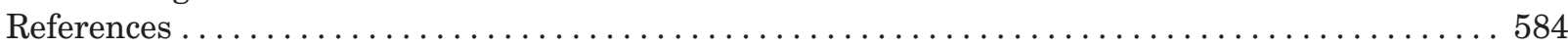

Abstract - Lysophospholipids are cell membranederived lipids that include both glycerophospholipids such as lysophosphatidic acid (LPA) and sphingoid lipids such as sphingosine 1-phosphate (S1P). These and related molecules can function in vertebrates as extracellular signals by binding and activating $G$ protein-coupled receptors. There are currently five LPA receptors, along with a proposed sixth $\left(\mathbf{L P A}_{1}-\mathbf{L P A}_{6}\right)$, and five S1P receptors $\left(\mathbf{S 1 P}_{1}-\mathbf{S 1 P}_{5}\right)$. A remarkably di-

Address correspondence to: Jerold Chun, Department of Molecular Biology, The Scripps Research Institute, 10550 N. Torrey Pines Rd., La Jolla, CA 92037. E-mail: jchun@scripps.edu

This article is available online at http://pharmrev.aspetjournals.org. doi:10.1124/pr.110.003111. verse biology and pathophysiology has emerged since the last review, driven by cloned receptors and targeted gene deletion ("knockout") studies in mice, which implicate receptor-mediated lysophospholipid signaling in most organ systems and multiple disease processes. The entry of various lysophospholipid receptor modulatory compounds into humans through clinical trials is ongoing and may lead to new medicines that are based on this signaling system. This review incorporates IUPHAR Nomenclature Committee guidelines in updating the nomenclature for lysophospholipid receptors (http://www.iuphar-db.org/ DATABASE/FamilyMenuForward?familyId=36). 


\section{Introduction}

Lysophosphatidic acid $\left(\mathrm{LPA}^{1}\right)$ and sphingosine 1-phosphate (S1P) are phospholipids derived from the cell membrane that also act as extracellular signals in vertebrates. Over the last decade, a consensus has emerged that most major extracellular actions of these lipids are mediated by predicted 7-transmembrane domain, G protein-coupled receptors (GPCRs). The identification of cognate receptors for LPA (Hecht et al., 1996) and S1P (Lee et al., 1998) that bore homology to one another led to the cloning of related genes, referred to initially as endothelial differentiation genes (EDGs), that encode for eight of the accepted lysophospholipid receptors. In addition, other GPCR genes with less homology have also been identified as LPA receptors (Noguchi et al., 2003; Kotarsky et al., 2006; Lee et al., 2006). The latter genes are more closely related to the family of P2Y purinergic receptor genes, indicating that LPA receptors have evolved through two distinct lineages in the rhodopsin GPCR family. A remarkable extent of heterogeneity for receptor subtypes, gene expression patterns, and effector pathways has underscored the diverse biological potential of receptor-mediated lysophospholipid signaling. This expectation has been met through studies of receptor knockout mice that have been reported for most of the identified receptors (Choi et al., 2008; Lee et al., 2008). The production of potent agonists and antagonists for some of these receptors has provided new insights into the therapeutic potential of this signaling system, the most prominent example being FTY720 (fingolimod), a sphingosine analog that, upon phosphorylation, becomes a receptor nonselective agonist at four of five S1P receptors (Chun and Hartung, 2010). In September 2010, fingolimod received U.S. Food and Drug Administration approval, with the commercial name Gilenya, in view of the results from two phase III clinical trials, as a first-line therapy for relapsingremitting multiple sclerosis (Cohen et al., 2010; Kappos et al., 2010).

\footnotetext{
${ }^{1}$ Abbreviations: CAY10444, 2-undecyl-thiazolidine-4-carboxylic acid; CNS, central nervous system; EDG, endothelial differentiation gene; FTY720, fingolimod; GPCR, G protein-coupled receptor; IUPHAR, International Union of Basic and Clinical Pharmacology; JTE013, N-(2,6-dichloro-4-pyridinyl)-2-[1,3-dimethyl-4-(1-methylethyl)-1H-pyrazolo[3,4-b]pyridin-6-yl]-hydrazinecarboxamide; Ki16425, 3-[[[4-[4-[[[1-(2-chlorophenyl)ethoxy]carbonyl]amino]-3-methyl-5-isoxazoly]phenyl]methyl]thio]-propanoic acid; KRP-203, 2-ammonio-4-(2chloro-4-(3-phenoxyphenylthio)phenyl)-2-(hydroxymethyl)butyl hydrogen phosphate; LPA, lysophosphatidic acid; S1P, sphingosine 1-phosphate; SEW2871, 5-[4-phenyl-5-(trifluoromethyl)-2-thienyl]-3-[3-(trifluoromethyl) phenyl]-1,2,4-oxadiazole; VPC 23019, $(R)$-phosphoric acid mono-[2-amino2-(3-octyl-phenylcarbamoyl)-ethyl] ester; VPC 23153, $(R)$-phosphoric acid mono-[2-amino-2-(6-octyl-1H-benzoimiazol-2-yl)-ethyl] ester; VPC 24191, (S)-phosphoric acid mono-[2-amino-3-(4-octyl-phenylamino)-propyl] ester; VPC12249, (S)-phosphoric acid mono-[3-(4-benzyloxy-phenyl)-2-octadec-9enoylamino-propyl] ester (ammonium salt); W140, 3-amino-4-(3-hexylphenylamino)-4-oxobutyl phosphonic acid; W146, ( $R$ )-3-amino-(3-hexylphenylamino)-4-oxobutylphosphonic acid.
}

More receptor-related details, as well as review of important enzymological mechanisms involved in ligand production, can be found in recent reviews on LPA receptors (Anliker and Chun, 2004; Ishii et al., 2004; Chun, 2005; Herr and Chun, 2007; Choi et al., 2008; Rivera and Chun, 2008; Noguchi et al., 2009; Skoura and Hla, 2009; Teo et al., 2009; Choi et al., 2010), LPA enzymology (Moolenaar et al., 2004; Aoki et al., 2008), and S1P receptors (Saba, 2004; Chun, 2005; Kono et al., 2008; Rivera et al., 2008; Maceyka et al., 2009; Skoura and Hla, 2009). This review focuses primarily on updating the IUPHAR nomenclature for the currently recognized lysophospholipid receptors, all of which are GPCRs.

\section{Lysophospholipid Receptor Nomenclature}

The currently accepted group of lysophospholipid receptors for LPA (along with the proposed addition of $\mathrm{LPA}_{6}$ ) and S1P are noted (Table 1). Receptor protein names are referred to as $\mathrm{LPA}_{x}$ with $x=1$ to 6 , or $\mathrm{S} \mathrm{P}_{x}$, with $x=1$ to 5 . Gene names in the literature include the original orphan names, especially "EDG," with current functional gene names used by the Human Genome Organization nomenclature committee (http://www.hugointernational.org/index.php) for human genes and the Mouse Genome Informatix (http://www.informatics.jax. org/) gene names for murine species. The Human Genome Organization names are LPARX or S1PRX, whereas Mouse Genome Informatix names are LparX and $S 1 p r X$, with $X=1$ to 6 for LPA receptor genes and $X=1$ to 5 for $\mathrm{S} 1 \mathrm{P}$ receptor genes. In addition to the discovery of new LPA receptors since the last review, two reports on putative receptors for the lysophospholipids sphingosylphosphorylcholine (Xu et al., 2000) and lysophosphatidylcholine (Kabarowski et al., 2001) have been retracted (Witte et al., 2005; Xu et al., 2006). For simplicity, receptor names will be used herein along with an indication of the species from which data were obtained. A summary of receptor names, gene names, and related information is presented in Table 1.

\section{A. Lysophosphatidic Acid Receptors}

There are currently five bona fide, apparent high-affinity cognate GPCRs for lysophosphatidic acid $\left(\mathrm{LPA}_{1}-\mathrm{LPA}_{5}\right)$ along with a proposed 6 th receptor, $\mathrm{LPA}_{6}$. There may be other receptors as well; therefore, this group should be considered a work in progress. Since the last IUPHAR Nomenclature Report (Chun et al., 2002), the three new LPA receptors that have been added are numbered based upon the date of their initial report, independent validation, and IUPHAR committee consensus: $\mathrm{LPA}_{4}$ to $\mathrm{LPA}_{6}$. Additional details on LPA receptor knockouts, biological and pathophysiological aspects, along with additional chemical tools, can be found elsewhere (e.g., Choi et al., 2010). 


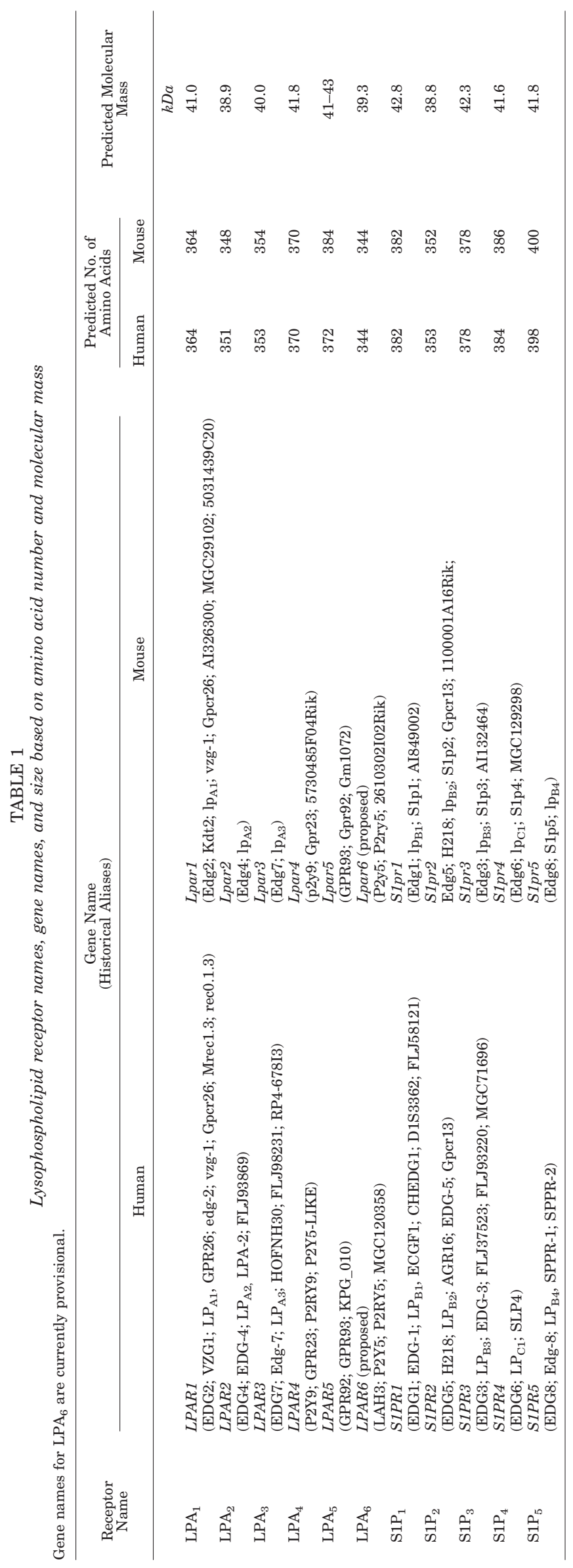

1. $L P A_{1}$. This was the first lysophospholipid receptor to be functionally identified (Hecht et al., 1996; for review, see Fukushima et al., 2001; Ishii et al., 2004). It was known previously by orphan names VZG-1, EDG-2, mrec1.3, and $\mathrm{lp}_{\mathrm{A} 1}$. The human gene for $\mathrm{LPA}_{1}$ encodes a $\sim 41-\mathrm{kDa}$ protein of 364 amino acids. It interacts with the heterotrimeric $G$ proteins $G_{i / o}, G_{q / 11}$, and $G_{12 / 13}$ (Fukushima et al., 1998; Ishii et al., 2000). Constitutive gene deletion in mice (Contos et al., 2000a,b, 2002) has revealed association with a wide range of developmental effects, particularly in the central nervous system (CNS) (Contos et al., 2000a,b; Kingsbury et al., 2003; EstivillTorrús et al., 2008; Matas-Rico et al., 2008; Santin et al., 2009; Castilla-Ortega et al., 2010; Dubin et al., 2010), as well as organismal survival (50\% perinatal death; Contos et al., 2000a,b, 2002), and receptor loss has been linked to multiple disease processes including cancer (Hama et al., 2004), the initiation of neuropathic pain (Inoue et al., 2004, 2006, 2008), fibrosis in kidney (Pradère et al., 2007) and lung (Tager et al., 2008), and male infertility (Ye et al., 2008), in conjunction with loss of other LPA receptors.

2. $L P A_{2} . \quad L^{2} A_{2}$ is a receptor with $\sim 60 \%$ amino acid similarity to $L P A_{1}$, with a predicted amino acid sequence of 348 amino acid residues and molecular mass of $\sim 39$ $\mathrm{kDa}$ (An et al., 1998; Contos et al., 2000a,b). Prior names include EDG-4 and $\operatorname{lp}_{\mathrm{A} 2}$. This receptor interacts with

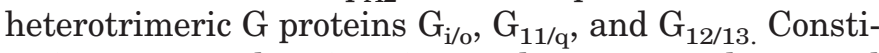
tutive receptor loss in mice produces a grossly normal phenotype; however, this receptor contributes to LPA signaling in the developing nervous system (Kingsbury et al., 2003; Dubin et al., 2010), synaptic functions in the adult CNS (Trimbuch et al., 2009), and effects on the male reproductive system (Ye et al., 2008), on the basis of the combined deletion of multiple LPA receptors, and has also been linked to some forms of cancer (Lin et al., 2009) and lung function in asthma (Zhao et al., 2009).

3. $L P A_{3}$. $\quad \mathrm{LPA}_{3}$, formerly known as EDG-7 and $\mathrm{lp}_{\mathrm{A} 3}$ (Bandoh et al., 1999; Im et al., 2000b; Fukushima et al., 2001 ) is a $\sim 40 \mathrm{kDa}$ GPCR that in mouse is $\sim 50 \%$ identical in amino acid sequence to $\mathrm{LPA}_{1}$ and $\mathrm{LPA}_{2}$. As with $\mathrm{LPA}_{1}$ and $\mathrm{LPA}_{2}$, it can couple with $\mathrm{G}_{\mathrm{i} / \mathrm{o}}$ and $\mathrm{G}_{\mathrm{q}}$. It is more potently activated by 2-acyl-LPA with unsaturated fatty acids (Bandoh et al., 1999; Sonoda et al., 2002). Constitutive loss of $\mathrm{LPA}_{3}$ in mice results in delayed and abnormal embryo implantation in the uterus (Ye et al., 2005; Hama et al., 2007) and contributes to male infertility in conjunction with $\mathrm{LPA}_{1}$ and $\mathrm{LPA}_{2}$ (Ye et al., 2008). Influences on dendritic cell chemotaxis have also been reported (Chan et al., 2007).

4. $L P A_{4}$. $\quad \mathrm{LPA}_{4}$ was an orphan receptor referred to as GPR23, p2y9, and p2y5-like (Janssens et al., 1997; O'Dowd et al., 1997). It was the first dissimilar LPA receptor to be identified, compared with the eight previously identified lysophospholipid receptors, and is located on the X chromosome (Noguchi et al., 2003). It has 370 amino acids with a predicted molecular mass of $\sim 42$ 
kDa (Janssens et al., 1997; O’Dowd et al., 1997) and couples to $\mathrm{G}_{12 / 13}, \mathrm{G}_{\mathrm{q} / 11}, \mathrm{G}_{\mathrm{i}}$, as well as $\mathrm{G}_{\mathrm{s}}$ (Lee et al., 2007; Yanagida et al., 2009). Constitutive gene deletion in mice produces grossly normal animals with some reported defects on cell motility (Lee et al., 2008), as revealed in culture studies, whereas an independent study (Sumida et al., 2010) identified partially penetrant functions of homozygous deletion in embryonic blood and lymphatic vessel formation.

5. $L P A_{5}$. The orphan receptor gene GPR92 was shown to encode a 5th LPA receptor, now referred to as LPA $_{5}$ (Kotarsky et al., 2006; Lee et al., 2006). Human $\mathrm{LPA}_{5}$ is composed of a 372 -amino acid protein with a predicted molecular mass of $\sim 41 \mathrm{kDa}$ and shares $\sim 35 \%$ homology with $\mathrm{LPA}_{4}$ (Lee et al., 2006). It couples to $\mathrm{G}_{12 / 13}$ and $\mathrm{G}_{\mathrm{q}}$ (Kotarsky et al., 2006; Lee et al., 2006). Farnesyl pyrophosphate and $N$-arachidonylglycine were proposed as $\mathrm{LPA}_{5}$ ligands (Oh et al., 2008). However, further independent studies indicated that $\mathrm{LPA}_{5}$ is a legitimate LPA receptor (Williams et al., 2009; Yin et al., 2009). It has been proposed that $\mathrm{LPA}_{5}$ is an alkyl (ether) LPA-preferring receptor (Williams et al., 2009). Ether LPAs, which are less potent than ester LPAs at LPA 1 to $\mathrm{LPA}_{3}$, are clearly more potent at platelet aggregation. Constitutive gene deletion in mice has not been reported.

6. $L P A_{6}$. The committee generally supported the inclusion of the orphan receptor P2Y5 as $\mathrm{LPA}_{6}$ on the basis of the emerging literature (Pasternack et al., 2008; Lee et al., 2009; Yanagida et al., 2009); however, the atypical functions of this receptor in standard assays led most to recommend circumspection with this identity, which continues to be clarified. $\mathrm{LPA}_{6}$ is most closely related to $\mathrm{LPA}_{4}$. Genetic studies also support the view that it encodes a functional LPA receptor, where it has been shown to influence forms of human hair growth (Pasternack et al., 2008; Shinkuma et al., 2010). Its gene structure is that of a nested gene within intron 17 of the retinoblastoma gene and encodes a 344 -amino acid protein with a predicted molecular mass of $\sim 39 \mathrm{kDa}$. $\mathrm{LPA}_{6}$ couples to $\mathrm{G}_{12 / 13}$ and $\mathrm{G}_{\mathrm{i}}$ (Lee et al., 2009; Yanagida et al., 2009). It was reported that 2-acyl-LPA rather than 1-acyl-LPA is the preferred ligand of $\mathrm{LPA}_{6}$ (Yanagida et al., 2009). Constitutive deletion in mice has not been reported but would be expected to phenocopy major aspects of human receptor loss that affect forms of hair growth. It is noteworthy that homozygous inactivation of $\mathrm{LPA}_{6}$ has also been implicated in bladder cancer development through unclear mechanisms that may reduce the activity of the tumor suppressor gene, RB1 (Lee et al., 2007).

7. Other Proposed Receptors. Three other orphan GPCRs have been proposed as new LPA receptors: GPR87, P2Y10 (Tabata et al., 2007; Murakami et al., 2008; Pasternack et al., 2008), and GPR35 (Oka et al., 2010). A consensus was reached to exclude these putative LPA receptors from the current list of six LPA receptors, which could change in the future based upon further experimental validation. Non-GPCR LPA receptors have also been reported and require further validation (McIntyre et al., 2003).

\section{B. Sphingosine 1-Phosphate Receptors}

At the present time, there are a total of five bona fide apparent high-affinity cognate GPCRs for $\mathrm{S} 1 \mathrm{P}\left(\mathrm{S}_{\mathrm{P}} \mathrm{P}_{1}-\right.$ $\mathrm{S} \mathrm{P}_{5}$ ). Since the last IUPHAR Nomenclature Report in 2002 (Chun et al., 2002), no new S1P receptors have been reported. All of the $\mathrm{S} 1 \mathrm{P}$ receptors specifically bind both S1P, dihydro-S1P (also called sphinganine 1-phosphate), and phytoS1P (4-hydroxysphinganine 1-phosphate) with low nanomolar affinities. Other sphingolipids (such as sphingosylphosphorylcholine) may activate these receptors at very high (micromolar), generally nonphysiological concentrations, and there is no evidence yet for additional endogenous ligands.

1. $S 1 P_{1}$. $\quad \mathrm{S}_{1} \mathrm{P}_{1}$, previously named EDG-1, was the first $\mathrm{S} 1 \mathrm{P}$ receptor to be functionally identified (Lee et al., 1998) [reviewed in (Fukushima et al., 2001; Ishii et al., 2004)]. Human $\mathrm{S}_{1} \mathrm{P}_{1}$ contains a 381 amino acid that shares $94 \%$ sequence identity with the murine receptor. $\mathrm{S}_{1} \mathrm{P}_{1}$ couples exclusively to $\mathrm{G}_{\mathrm{i} / \mathrm{o}}$. Because $\mathrm{S}_{\mathrm{P}} \mathrm{P}_{1}$ activates the protein kinase Akt and the small GTPase Rac, activation of $\mathrm{S}_{1} \mathrm{P}_{1}$ results in the formation of lamellapodia and cell-cell junctions (adherens junctions) (Lee et al., 1999, 2001).

Constitutive receptor loss results in embryonic lethality (Liu et al., 2000), affecting vasculature and nervous system development. $\mathrm{S} \mathrm{P}_{1}$ was the first example of a lysophospholipid receptor that was required for embryonic development, and it plays a major role in angiogenesis and vascular development (Kono et al., 2004), neurogenesis (Mizugishi et al., 2005), and trafficking of lymphocytes, as well as other hematopoietic cells, on the basis of data from both constitutive and conditional mutants that have also

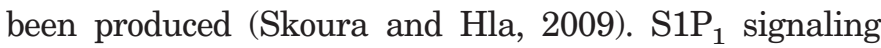
under physiological homeostasis is needed for maintenance of basal permeability barriers of the vascular system. Administration of one class of pharmacological antagonists of $\mathrm{S}_{1} \mathrm{P}_{1}$ led to marked increases in basal permeability of the mouse lung (Foss et al., 2006; Sanna et

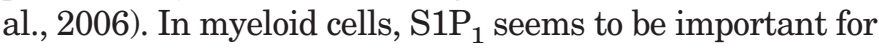
maintaining the expression of genes that mediate antiinflammatory mechanisms (Hughes et al., 2008).

2. $S 1 P_{2}$. This receptor was previously known as EDG-5, H218, AGR16, and $\mathrm{lp}_{\mathrm{B} 2}$. It participates in S1Pinduced cell proliferation, motility, and transcriptional activation, generally acting in opposition to $\mathrm{S}_{1} \mathrm{P}_{1}$ (Skoura and Hla, 2009). Human $\mathrm{S} \mathrm{P}_{2}$ contains 353 amino acids and is highly conserved across species. Although $\mathrm{S} \mathrm{P}_{2}$ can couple to $\mathrm{G}_{\mathrm{i} / \mathrm{o}}, \mathrm{G}_{\mathrm{s}}, \mathrm{G}_{\mathrm{q}}$, and $\mathrm{G}_{12 / 13}$, it couples most efficiently to $G_{12 / 13}$ and potently activates the small GTPase Rho (Gonda et al., 1999; Windh et al., 1999; Okamoto et al., 2000). 
Constitutive gene deletion has shown that although $\mathrm{S} \mathrm{P}_{2}$ is not necessary for normal development, this receptor cooperates with $\mathrm{S}_{1} \mathrm{P}_{1}$ during vascular development (Kono et al., 2004). Lack of $\mathrm{S}_{2} \mathrm{P}_{2}$ led to hearing and balance defects as a result of alterations in hair cells, support cells, and vasculature (stria vascularis) of the inner ear (Kono et al., 2007), although other mechansims related to direct protection of hair cells likely also occur (MacLennan et al., 2006; Herr et al., 2007). $\mathrm{S} \mathrm{P}_{2}$ also promotes pathologic angiogenesis and retards normal vascularization in the retinas of mice during hypoxia-induced retinopathy [on the basis of loss-of-function in receptor-null animals (Skoura et al., 2007)] and, in conjunction with $\mathrm{S}_{1} \mathrm{P}_{3}$, can provide protection in myocardial ischemia-reperfusion models (Means et al., 2007). It has similarly been linked to reduced fertility, in conjunction with $\mathrm{S}_{1} \mathrm{P}_{3}$ loss (Ishii et al., 2002), as well as to hepatic wound healing, fibrosis, and regenerative capacity (Serriere-Lanneau et al., 2007; Ikeda et al., 2009).

3. $S 1 P_{3}$. Human $\mathrm{S} \mathrm{P}_{3}$ contains 378 amino acids that are $92 \%$ homologous to the murine $\mathrm{S}_{1} \mathrm{P}_{3}$ receptor. It was previously known as EDG-3 and $\mathrm{lp}_{\mathrm{B} 3}$. Like $\mathrm{S}_{2} \mathrm{P}_{2}, \mathrm{~S}_{1} \mathrm{P}_{3}$ can couple with $\mathrm{G}_{\mathrm{i} / \mathrm{o}}, \mathrm{G}_{\mathrm{q}}$, and $\mathrm{G}_{12 / 13}$ (Ancellin and Hla, 1999; Windh et al., 1999). However, it most efficiently couples to the $G_{\mathrm{q}}$ protein and stimulates the hydrolysis of phosphatidylinositol bisphosphate, to form inositol 1,4,5-trisphosphate and thereby leading to intracellular $\mathrm{Ca}^{2+}$ increases and activation of protein kinase C. $\mathrm{S}_{3} \mathrm{P}_{3}$ binds S1P and dihydro-S1P with affinities in the $20 \mathrm{nM}$ range (Van Brocklyn et al., 1999).

Constitutive deletion (Ishii et al., 2001) did not reveal a gross phenotype but did contribute to infertility in conjunction with $\mathrm{S}_{1} \mathrm{P}_{2}$ loss (Ishii et al., 2002). A clear role for $\mathrm{S}_{1} \mathrm{P}_{3}$ has also been demonstrated in the regulation of heart rate in rodents (Forrest et al., 2004; Sanna et al., 2004), and it has been shown to regulate lymphoid endothelial cells (Girkontaite et al., 2004) and to have effects on endothelial progenitor cells (Walter et al., 2007). $\mathrm{S} 1 \mathrm{P}_{3}$ regulates myocardial perfusion and provides protection in ischemia-reperfusion injury (Levkau et al., 2004; Theilmeier et al., 2006; Means et al., 2007) and further influences vasorelaxation (Nofer et al., 2004) and cardiac fibrosis (Takuwa et al., 2009). Other influences on myofibroblasts (Keller et al., 2007), as well as $\mathrm{S}_{1} \mathrm{P}_{3}$ links to PAR-1 signaling that couples coagulation events with inflammation (Niessen et al., 2008), have been reported. Numerous abstracts and presentations have documented that bradycardia in primates, including humans, is driven by $\mathrm{S}_{1} \mathrm{P}_{1}$, in that its expression is localized to myocytes and perivascular smooth muscle cells, and its activation results in bradycardia and hypertension.

4. $\mathrm{S}_{4}$. Human $\mathrm{S}_{4}$, previously known as EDG-6 and $\mathrm{lp}_{\mathrm{C} 1}$, contains 384 amino acids that share $82 \%$ sequence identity with the murine $\mathrm{S}_{4} P_{4}$ receptor (Van Brocklyn et al., 2000). $\mathrm{S}_{\mathrm{P}} \mathrm{P}_{4}$ couples to $\mathrm{G}_{\mathrm{s}}, \mathrm{G}_{\mathrm{q}}$, and $\mathrm{G}_{12 / 13}$. $\mathrm{S} \mathrm{P}_{4}$ has been reported to be primarily expressed in lymphoid tissues (Graeler and Goetzl, 2002) and medi- ates immunosuppressive effects of S1P by inhibiting proliferation and secretion of effector cytokines (Wang et al., 2005). Null mouse mutants have not been reported.

5. $S 1 P_{5} . \quad \mathrm{S}^{2} \mathrm{P}_{5}$, known previously as EDG-8 and $\mathrm{lp}_{\mathrm{B} 4}$, was the last of the S1P receptors to be cloned. It shows restricted tissue distribution to brain and spleen (Im et al., 2000a; Malek et al., 2001). Human $\mathrm{S} \mathrm{P}_{5}$ has 398 amino acids (Malek et al., 2001), and it has high sequence homology with other S1P receptors in other mammalian species. It couples to $\mathrm{G}_{\mathrm{s}}, \mathrm{G}_{\mathrm{q}}$, and $\mathrm{G}_{12 / 13}$. Deletion of this receptor alters natural killer cell trafficking (Walzer et al., 2007), and recent studies on another $\mathrm{S} \mathrm{P}_{5}$ constitutive null-mouse mutant (Jenne et al., 2009) indicated that this receptor influences immunological natural killer cell egress through a T-bet/Tbx21 transcription factor mechanism involving various immunological compartments. Its expression in oligodendrocytes of the CNS points to other possible roles that require further study.

\section{Lysophospholipid Receptor Agonists/Antagonists}

\section{A. Lysophosphatidic Acid Receptor Compounds}

LPA receptor agonists include 1-oleoyl-2-O-methylrac-glycerophosphothionate (Hasegawa et al., 2003), with some selectivity for $\mathrm{LPA}_{3}$, fatty acid phosphates (Virag et al., 2003), and other possible agonist compounds (Jiang et al., 2007; Gajewiak et al., 2008). LPA receptor antagonists have been reported, with most compounds acting on $\mathrm{LPA}_{1}$ and $\mathrm{LPA}_{3}$ : 3-[[[4-[4-[[[1-(2-chlorophenyl)ethoxy]carbonyl]amino]-3-methyl-5-isoxazoly] phenyl]methyl]thio]-propanoic acid (Ki16425) (Ohta et al., 2003), (S)-phosphoric acid mono-[3-(4-benzyloxyphenyl)-2-octadec-9-enoylamino-propyl] ester (ammonium salt) (VPC12249), and related compounds (Heise et al., 2001; Okusa et al., 2003; Heasley et al., 2004a,b). The specificity of these agents, most of which are LPA analogs, must be re-examined in light of the discovery of additional LPA receptors. Investigations of LPA biology have been hampered by the lack of drug-like small molecules. Newer agents are under development by commercial entities targeting LPA signaling as a potential therapeutic target.

\section{B. Sphingosine 1-Phosphate Receptor Compounds}

The discovery that the immunosuppressant drug FTY720 (fingolimod) was converted by sphingosine kinase in vivo to a S1P mimetic that regulated lymphocyte trafficking by acting as an $\mathrm{S}_{1} \mathrm{P}_{1}$ agonist (Brinkmann et al., 2002; Mandala et al., 2002) spurred great interest in the development and use of $\mathrm{S} 1 \mathrm{P}$ receptor-targeted compounds. FTY720-P is an agonist at the $\mathrm{S}_{1} \mathrm{P}_{1}, \mathrm{~S}_{1} \mathrm{P}_{3}, \mathrm{~S}_{1} \mathrm{P}_{4}$, and $\mathrm{S}_{5} \mathrm{P}_{5}$ receptors (Brinkmann et al., 2002, 2007; Mandala et al., 2002). There are now several relatively specific agonists and antagonists for most of the S1P receptors that have been used to investigate the physiological roles of these 
receptors in many biological systems. 5-[4-Phenyl-5(trifluoromethyl)-2-thienyl]-3-[3-(trifluoromethyl)phenyl]1,2,4-oxadiazole (SEW2871) is a specific agonist for $\mathrm{S}_{1} \mathrm{P}_{1}$ (Sanna et al., 2004). Lynch and Macdonald and colleagues have characterized the very useful VPC series: $(R)$ phosphoric acid mono-[2-amino-2-(3-octyl-phenylcarbamoyl)-ethyl] ester (VPC 23019) is an antagonist for $\mathrm{S}_{1} \mathrm{P}_{1}$ at low micromolar concentrations and also functions at both $\mathrm{S}_{1} \mathrm{P}_{1}$ and $\mathrm{S}_{1} \mathrm{P}_{3}$ at concentrations above $10 \mu \mathrm{M}$ (Davis et al., 2005); (S)-phosphoric acid mono-[2-amino-3-(4-octylphenylamino)-propyl] ester (VPC 24191) and ( $R$ )-phosphoric acid mono-[2-amino-2-(6-octyl- $1 H$-benzoimiazol-2-yl)ethyl] ester (VPC 23153) are agonists at $\mathrm{S}_{1} \mathrm{P}_{1}$ and $\mathrm{S}_{3} \mathrm{P}_{3}$ (Clemens et al., 2003, 2004). $N$-(2,6-Dichloro-4-pyridinyl)2-[1,3-dimethyl-4-(1-methylethyl)-1H-pyrazolo[3,4-b]pyridin-6-yl]-hydrazinecarboxamide (JTE013) seems to be a specific antagonist at $\mathrm{S}_{2} \mathrm{P}_{2}$ (Osada et al., 2002; Sanchez et al., 2007). The $(R)$-3-amino-(3-hexylphenylamino)-4oxobutylphosphonic acid (W146)/3-amino-4-(3-hexylphenylamino)-4-oxobutyl phosphonic acid (W140) chiral pair is very useful; W146 is an $\mathrm{S} \mathrm{P}_{1}$ antagonist and its enantiomer, W140, is an agonist at the same receptor (GonzalezCabrera et al., 2008). Although still not well studied, it was reported that 2-undecyl-thiazolidine-4-carboxylic acid (CAY10444) is a specific $\mathrm{S} 1 \mathrm{P}_{3}$ antagonist (Koide et al., 2007). The success of FTY720 in the clinic has spurred the search for similar molecules, particularly with $\mathrm{S} \mathrm{P}_{3}$ sparing activity. FTY720-like prodrugs include 2-ammonio-4-(2-chloro-4-(3-phenoxyphenylthio)phenyl)-2-(hydroxymethyl)butyl hydrogen phosphate (KRP-203) (Shimizu et al., 2005) and 1-[1-amino-3-(4-octylphenyl)cyclopentyl]methanol (VPC01091) (Zhu et al., 2007) and are, after phosphorylation, agonists for $\mathrm{S}_{1} \mathrm{P}_{1}, \mathrm{~S}_{1} \mathrm{P}_{4}$, and $\mathrm{S}_{1} \mathrm{P}_{5}$ but not $\mathrm{S}_{1} \mathrm{P}_{2}$ or $\mathrm{S}_{1} \mathrm{P}_{3}$. Numerous compounds that target $\mathrm{S}_{1} \mathrm{P}_{1}$ and $\mathrm{S}_{1} \mathrm{P}_{5}$ as direct agonists have been described previously ( $\mathrm{Li}$ et al., 2005); most of these remain visible only in the patent literature.

\section{Biological Functions of Lysophosphatidic Acid and Sphingosine 1-Phosphate}

An enormous literature has emerged in which LPA and $\mathrm{S} 1 \mathrm{P}$ signaling has been implicated in most organ systems (for review, see Ishii et al., 2004; Gardell et al., 2006; Mutoh and Chun, 2008; Choi et al., 2010). This includes the nervous system (Ishii et al., 2004; Noguchi et al., 2009), immune system (Goetzl and An, 1999; Rubenfeld et al., 2006; Schwab and Cyster, 2007), reproductive system (Ye et al., 2005), and vascular system (Skoura and Hla, 2009; Teo et al., 2009). In addition, LPA, S1P, and their multiple receptors have been implicated in numerous human disease processes [many of which were noted in section II (Gardell et al., 2006)], including cancer (Mills and Moolenaar, 2003), fibrosis (Pradère et al., 2007; Tager et al., 2008), pain (Gardell et al., 2006), obesity (Simon et al., 2005; Yea et al., 2008), and, most importantly from the standpoint of a diseasemodifying therapy in humans, multiple sclerosis (Chun and Hartung, 2010). Because most cell lineages in the body express at least one and usually several subtypes of these lysophospholipid receptors, the involved organ systems and disease processes are likely to expand in the near future.

\section{Conclusions}

Lysophospholipid receptors now constitute a validated group of GPCRs that, with the inclusion of $\mathrm{LPA}_{6}$, comprise 11 different gene products. These receptors mediate both biological and pathophysiological effects of LPA, S1P, and possibly other lysophospholipids as well. It is likely that additional receptors will be identified for these and possibly other classes of lysophospholipids. The broad scope of effects that have been reported in the literature underscores the upward trajectory of this field. The prospect of an actual medicine entering clinical practice on the basis of this receptor-based systemfingolimod as an oral medication for treating relapsing multiple sclerosis-raises the hope that new compounds and treatable therapeutic indications will be identified in the coming years.

Acknowledgments. This work was supported by the National Institutes of Health National Institute of Mental Health [Grant MH051699]; the National Institute of Neurological Disorders and Stroke [Grant NS048478]; the National Institutes of Health National Institute of Child Health \& Human Development [Grant HD050685]; the National Institutes of Health National Institute on Drug Abuse [Grant DA019674]; the National Institutes of Health National Institute on Deafness and Other Communication Disorders [Grant DC009505] (all the preceding to J.C.); the National Institutes of Health National Institute of General Medical Sciences [Grants GM067958, GM052722 (to K.R.L.), GM043880 (to S.S.)]; the National Institutes of Health National Heart, Lung, and Blood Institute [Grants HL67330, HL89934, HL70694] (to T.H.); the National Institutes of Health National Cancer Institute [Grant CA6177412] (to S.S.); the National Institutes of Health National Institute of Allergy and Infectious Diseases Extramural Activities [Grants AI50094, AI077435] (to S.S.); and the Dutch Cancer Society (to W.H.M.). We sincerely thank Drs. J. Aoki, S. Ishii, and G. Tigyi for helpful discussions, along with our other colleagues whose important work has advanced this field, and we apologize for being unable to cite all relevant references. We thank D. Letourneau for editorial assistance. The authors are listed in alphabetical order.

\section{REFERENCES}

An S, Bleu T, Hallmark OG, and Goetzl EJ (1998) Characterization of a nove subtype of human $\mathrm{G}$ protein-coupled receptor for lysophosphatidic acid. J Bio Chem 273:7906-7910.

Ancellin N and Hla T (1999) Differential pharmacological properties and signal transduction of the sphingosine 1-phosphate receptors EDG-1, EDG-3, and EDG-5. J Biol Chem 274:18997-19002.

Anliker B and Chun J (2004) Cell surface receptors in lysophospholipid signaling. Semin Cell Dev Biol 15:457-465.

Aoki J, Inoue A, and Okudaira S (2008) Two pathways for lysophosphatidic acid production. Biochim Biophys Acta 1781:513-518.

Bandoh K, Aoki J, Hosono H, Kobayashi S, Kobayashi T, Murakami-Murofushi K, Tsujimoto M, Arai H, and Inoue K (1999) Molecular cloning and characterization of a novel human G-protein-coupled receptor, EDG7, for lysophosphatidic acid. $J$ Biol Chem 274:27776-27785.

Brinkmann V, Davis MD, Heise CE, Albert R, Cottens S, Hof R, Bruns C, Prieschl E, Baumruker T, Hiestand P, et al. (2002) The immune modulator FTY720 targets sphingosine 1-phosphate receptors. J Biol Chem 277:21453-21457.

Brinkmann V (2007) Sphingosine 1-phosphate receptors in health and disease: mechanistic insights from gene deletion studies and reverse pharmacology. Phar macol Ther 115:84-105.

Castilla-Ortega E, Sánchez-López J, Hoyo-Becerra C, Matas-Rico E, Zambrana- 
Infantes E, Chun J, De Fonseca FR, Pedraza C, Estivill-Torrús G, and Santin LJ (2010) Exploratory, anxiety and spatial memory impairments are dissociated in mice lacking the LPA1 receptor. Neurobiol Learn Mem 94:73-82.

Chan LC, Peters W, Xu Y, Chun J, Farese RV Jr, and Cases S (2007) LPA receptor $^{2}$ mediates chemotaxis of immature murine dendritic cells to unsaturated lysophosphatidic acid (LPA). J Leukoc Biol 82:1193-1200.

Choi JW, Lee CW, and Chun J (2008) Biological roles of lysophospholipid receptors revealed by genetic null mice: an update. Biochim Biophys Acta 1781:531-539.

Choi JW, Herr DR, Noguchi K, Yung YC, Lee CW, Mutoh T, Lin ME, Teo ST, Park KE, Mosley AN, et al. (2010) LPA receptors: subtypes and biological actions. Annu Rev Pharmacol Toxicol 50:157-186.

Chun J (2005) Lysophospholipids in the nervous system. Prostaglandins Other Lipid Mediat 77:46-51.

Chun J, Goetzl EJ, Hla T, Igarashi Y, Lynch KR, Moolenaar W, Pyne S, and Tigyi G (2002) International Union of Pharmacology. XXXIV. Lysophospholipid receptor nomenclature. Pharmacol Rev 54:265-269.

Chun J and Hartung HP (2010) Mechanism of action of oral fingolimod (FTY720) in multiple sclerosis. Clin Neuropharmacol 33:91-101.

Clemens JJ, Davis MD, Lynch KR, and Macdonald TL (2003) Synthesis of para-alkyl aryl amide analogues of sphingosine-1-phosphate: discovery of potent S1P receptor agonists. Bioorg Med Chem Lett 13:3401-3404.

Clemens JJ, Davis MD, Lynch KR, and Macdonald TL (2004) Synthesis of benzimidazole based analogues of sphingosine-1-phosphate: discovery of potent, subtypeselective $\mathrm{S} 1 P_{4}$ receptor agonists. Bioorg Med Chem Lett 14:4903-4906.

Cohen JA, Barkhof F, Comi G, Hartung HP, Khatri BO, Montalban X, Pelletier J, Capra R, Gallo P, Izquierdo G, et al. (2010) Oral fingolimod or intramuscular interferon for relapsing multiple sclerosis. $N$ Engl $J$ Med 362:402-415

Contos JJ, Fukushima N, Weiner JA, Kaushal D, and Chun J (2000a) Requirement for the lpA1 lysophosphatidic acid receptor gene in normal suckling behavior. Proc Natl Acad Sci USA 97:13384-13389.

Contos JJ, Ishii I, and Chun J (2000b) Lysophosphatidic acid receptors. Mol Pharmacol 58:1188-1196.

Contos JJ, Ishii I, Fukushima N, Kingsbury MA, Ye X, Kawamura S, Brown JH, and Chun J (2002) Characterization of lpa(2) (Edg4) and lpa(1)/lpa(2) (Edg2/Edg4) lysophosphatidic acid receptor knockout mice: signaling deficits without obvious phenotypic abnormality attributable to lpa(2). Mol Cell Biol 22:6921-6929.

Davis MD, Clemens JJ, Macdonald TL, and Lynch KR (2005) Sphingosine 1-phosphate analogs as receptor antagonists. J Biol Chem 280:9833-9841.

Dubin AE, Herr DR, and Chun J (2010) Diversity of lysophosphatidic acid receptormediated intracellular calcium signaling in early cortical neurogenesis. J Neurosci 30:7300-7309.

Estivill-Torrús G, Llebrez-Zayas P, Matas-Rico E, Santín L, Pedraza C, De Diego I, Del Arco I, Fernández-Llebrez P, Chun J, and De Fonseca FR (2008) Absence of $\mathrm{LPA}_{1}$ signaling results in defective cortical development. Cereb Cortex 18:938-950.

Forrest M, Sun SY, Hajdu R, Bergstrom J, Card D, Doherty G, Hale J, Keohane C Meyers C, Milligan J, et al. (2004) Immune cell regulation and cardiovascular effects of sphingosine 1-phosphate receptor agonists in rodents are mediated via distinct receptor subtypes. J Pharmacol Exp Ther 309:758-768.

Foss FW Jr, Snyder AH, Davis MD, Rouse M, Okusa MD, Lynch KR, and Macdonald TL (2006) Synthesis and biological evaluation of $\gamma$-aminophosphonates as potent sub-type selective sphingosine 1-phosphate receptor agonists and antagonists. Bioorg Med Chem 15:663-677.

Fukushima N, Ishii I, Contos JJ, Weiner JA, and Chun J (2001) Lysophospholipid receptors. Annu Rev Pharmacol Toxicol 41:507-534.

Fukushima N, Kimura Y, and Chun J (1998) A single receptor encoded by vzg-1/ lpA1/edg-2 couples to $\mathrm{G}$ proteins and mediates multiple cellular responses to lysophosphatidic acid. Proc Natl Acad Sci USA 95:6151-6156.

Gajewiak J, Tsukahara R, Fujiwara Y, Tigyi G, and Prestwich GD (2008) Synthesis, pharmacology, and cell biology of sn-2-aminooxy analogues of lysophosphatidic acid. Org Lett 10:1111-1114.

Gardell SE, Dubin AE, and Chun J (2006) Emerging medicinal roles for lysophospholipid signaling. Trends Mol Med 12:65-75.

Girkontaite I, Sakk V, Wagner M, Borggrefe T, Tedford K, Chun J, and Fischer KD (2004) The sphingosine-1-phosphate (S1P) lysophospholipid receptor $\mathrm{S}_{1} \mathrm{P}_{3}$ regulates MAdCAM-1 $1^{+}$endothelial cells in splenic marginal sinus organization. $J$ Exp Med 200:1491-1501.

Goetzl EJ and An S (1999) A subfamily of G protein-coupled cellular receptors for lysophospholipids and lysosphingolipids. Adv Exp Med Biol 469:259-264.

Gonda K, Okamoto H, Takuwa N, Yatomi Y, Okazaki H, Sakurai T, Kimura S, Sillard R, Harii K, and Takuwa Y (1999) The novel sphingosine 1-phosphate receptor AGR16 is coupled via pertussis toxin-sensitive and -insensitive Gproteins to multiple signalling pathways. Biochem $J$ 337:67-75

Gonzalez-Cabrera PJ, Jo E, Sanna MG, Brown S, Leaf N, Marsolais D, Schaeffer MT, Chapman J, Cameron M, Guerrero M, et al. (2008) Full pharmacological efficacy of a novel $\mathrm{S}_{\mathrm{P}} \mathrm{P}_{1}$ agonist that does not require $\mathrm{S} 1 \mathrm{P}$-like headgroup interactions. $\mathrm{Mol}$ Pharmacol 74:1308-1318.

Graeler M and Goetzl EJ (2002) Activation-regulated expression and chemotactic function of sphingosine 1-phosphate receptors in mouse splenic T cells. FASEB $J$ 16:1874-1878.

Hama K, Aoki J, Fukaya M, Kishi Y, Sakai T, Suzuki R, Ohta H, Yamori T, Watanabe M, Chun J, et al. (2004) Lysophosphatidic acid and autotaxin stimulate cell motility of neoplastic and non-neoplastic cells through LPA1. J Biol Chem 279:17634-17639.

Hama K, Aoki J, Inoue A, Endo T, Amano T, Motoki R, Kanai M, Ye X, Chun J Matsuki N, et al. (2007) Embryo spacing and implantation timing are differentially regulated by LPA3-mediated lysophosphatidic acid signaling in mice. Biol Reprod 77:954-959.

Hasegawa Y, Erickson JR, Goddard GJ, Yu S, Liu S, Cheng KW, Eder A, Bandoh K, Aoki J, Jarosz R, et al.(2003) Identification of a phosphothionate analogue of lysophosphatidic acid (LPA) as a selective agonist of the $\mathrm{LPA}_{3}$ receptor. J Biol Chem 278:11962-11969.
Heasley BH, Jarosz R, Carter KM, Van SJ, Lynch KR, and Macdonald TL (2004a) A novel series of 2-pyridyl-containing compounds as lysophosphatidic acid receptor antagonists: development of a nonhydrolyzable LPA3 receptor-selective antagonist. Bioorg Med Chem Lett 14:4069-4074

Heasley BH, Jarosz R, Lynch KR, and Macdonald TL (2004b) Initial structureactivity relationships of lysophosphatidic acid receptor antagonists: discovery of a high-affinity $\mathrm{LPA}_{1} / \mathrm{LPA}_{3}$ receptor antagonist. Bioorg Med Chem Lett 14:27352740.

Hecht JH, Weiner JA, Post SR, and Chun J (1996) Ventricular zone gene-1 (vzg-1) encodes a lysophosphatidic acid receptor expressed in neurogenic regions of the developing cerebral cortex. J Cell Biol 135:1071-1083.

Heise CE, Santos WL, Schreihofer AM, Heasley BH, Mukhin YV, Macdonald TL, and Lynch KR (2001) Activity of 2-substituted lysophosphatidic acid (LPA) analogs at LPA receptors: discovery of a $\mathrm{LPA}_{1} / \mathrm{LPA}_{3}$ receptor antagonist. Mol Pharmacol 60: $1173-1180$

Herr DR and Chun J (2007) Effects of LPA and S1P on the nervous system and implications for their involvement in disease. Curr Drug Targets 8:155-167.

Herr DR, Grillet N, Schwander M, Rivera R, Müller U, and Chun J (2007) Sphin gosine 1-phosphate (S1P) signaling is required for maintenance of hair cells mainly via activation of $\mathrm{S}_{1} \mathrm{P}_{2}, J$ Neurosci 27:1474-1478.

Hughes JE, Srinivasan S, Lynch KR, Proia RL, Ferdek P, and Hedrick CC (2008) Sphingosine-1-phosphate induces an antiinflammatory phenotype in macro phages. Circ Res 102:950-958.

Ikeda H, Watanabe N, Ishii I, Shimosawa T, Kume Y, Tomiya T, Inoue Y, Nishikawa T, Ohtomo N, Tanoue Y, et al. (2009) Sphingosine 1-phosphate regulates regeneration and fibrosis after liver injury via sphingosine 1-phosphate receptor $2 . J$ Lipid Res 50:556-564.

Im DS, Heise CE, Ancellin N, O’Dowd BF, Shei GJ, Heavens RP, Rigby MR, Hla T, Mandala S, McAllister G, et al. (2000a) Characterization of a novel sphingosine 1-phosphate receptor, Edg-8. J Biol Chem 275:14281-14286.

Im DS, Heise CE, Harding MA, George SR, O'Dowd BF, Theodorescu D, and Lynch KR (2000b) Molecular cloning and characterization of a lysophosphatidic acid receptor, Edg-7, expressed in prostate. Mol Pharmacol 57:753-759.

Inoue M, Rashid MH, Fujita R, Contos JJ, Chun J, and Ueda H (2004) Initiation of neuropathic pain requires lysophosphatidic acid receptor signaling. Nat Med 10: $712-718$

Inoue M, Xie W, Matsushita Y, Chun J, Aoki J, and Ueda H (2008) Lysophosphatidylcholine induces neuropathic pain through an action of autotaxin to generate lysophosphatidic acid. Neuroscience 152:296-298.

Inoue M, Yamaguchi A, Kawakami M, Chun J, and Ueda H (2006) Loss of spinal substance $\mathrm{P}$ pain transmission under the condition of LPA1 receptor-mediated neuropathic pain. Mol Pain 2:25

Ishii I, Contos JJ, Fukushima N, and Chun J (2000) Functional comparisons of the lysophosphatidic acid receptors, LP(A1)/VZG-1/EDG-2, LP(A2)/EDG-4, and LP(A3)/EDG-7 in neuronal cell lines using a retrovirus expression system. Mol Pharmacol 58:895-902.

Ishii I, Friedman B, Ye X, Kawamura S, McGiffert C, Contos JJ, Kingsbury MA Zhang G, Brown JH, and Chun J (2001) Selective loss of sphingosine 1-phosphate signaling with no obvious phenotypic abnormality in mice lacking its $\mathrm{G}$ protein coupled receptor, LP(B3)/EDG-3. J Biol Chem 276:33697-33704.

Ishii I, Fukushima N, Ye X, and Chun J (2004) Lysophospholipid receptors: signaling and biology. Annu Rev Biochem 73:321-354.

Ishii I, Ye X, Friedman B, Kawamura S, Contos JJ, Kingsbury MA, Yang AH, Zhang G, Brown JH, and Chun J (2002) Marked perinatal lethality and cellular signaling deficits in mice null for the two sphingosine 1-phosphate (S1P) receptors, $\mathrm{S} 1 \mathrm{P}(2)$ LP(B2)/EDG-5 and S1P(3)/LP(B3)/EDG-3. J Biol Chem 277:25152-25159.

Janssens R, Boeynaems JM, Godart M, and Communi D (1997) Cloning of a human heptahelical receptor closely related to the P2Y5 receptor. Biochem Biophys Res Commun 236:106-112

Jenne CN, Enders A, Rivera R, Watson SR, Bankovich AJ, Pereira JP, Xu Y, Root $\mathrm{CM}$, Beilke JN, Banerjee A, et al. (2009) T-bet-dependent $\mathrm{S} \mathrm{P}_{5}$ expression in NK cells promotes egress from lymph nodes and bone marrow. J Exp Med 206:24692481.

Jiang G, Xu Y, Fujiwara Y, Tsukahara T, Tsukahara R, Gajewiak J, Tigyi G, and Prestwich GD (2007) Alpha-substituted phosphonate analogues of lysophosphatidic acid (LPA) selectively inhibit production and action of LPA. ChemMedChem 2:679-690

Kabarowski JH, Zhu K, Le LQ, Witte ON, and Xu Y (2001) Lysophosphatidylcholine as a ligand for the immunoregulatory receptor G2A [Retraction appears in Science 307:206, 2005]. Science 293:702-705.

Kappos L, Radue EW, O'Connor P, Polman C, Hohlfeld R, Calabresi P, Selmaj K, Agoropoulou C, Leyk M, Zhang-Auberson L, et al. (2010) A placebo-controlled tria of oral fingolimod in relapsing multiple sclerosis. $N$ Engl J Med 362:387-401.

Keller CD, Rivera Gil P, Tölle M, van der Giet M, Chun J, Radeke HH, SchäferKorting M, and Kleuser B (2007) Immunomodulator FTY720 induces myofibroblast differentiation via the lysophospholipid receptor $\mathrm{S}_{1} \mathrm{P}_{3}$ and Smad3 signaling. Am J Pathol 170:281-292.

Kingsbury MA, Rehen SK, Contos JJ, Higgins CM, and Chun J (2003) Nonproliferative effects of lysophosphatidic acid enhance cortical growth and folding. Nat Neurosci 6:1292-1299.

Koide Y, Uemoto K, Hasegawa T, Sada T, Murakami A, Takasugi H, Sakurai A Mochizuki N, Takahashi A, and Nishida A (2007) Pharmacophore-based design of sphingosine 1-phosphate-3 receptor antagonists that include a 3,4-dialkoxybenzophenone scaffold. J Med Chem 50:442-454.

Kono M, Allende ML, and Proia RL (2008) Sphingosine-1-phosphate regulation of mammalian development. Biochim Biophys Acta 1781:435-441.

Kono M, Belyantseva IA, Skoura A, Frolenkov GI, Starost MF, Dreier JL, Lidington D, Bolz SS, Friedman TB, Hla T, et al. (2007) Deafness and stria vascularis defects in S1P2 receptor-null mice. J Biol Chem 282:10690-10696.

Kono M, Mi Y, Liu Y, Sasaki T, Allende ML, Wu YP, Yamashita T, and Proia RL 
(2004) The sphingosine-1-phosphate receptors $\mathrm{S}_{1} \mathrm{P}_{1}, \mathrm{~S}_{1} \mathrm{P}_{2}$, and $\mathrm{S}_{1} \mathrm{P}_{3}$ function coordinately during embryonic angiogenesis. J Biol Chem 279:29367-29373.

Kotarsky K, Boketoft A, Bristulf J, Nilsson NE, Norberg A, Hansson S, Owman C, Sillard R, Leeb-Lundberg LM, and Olde B (2006) Lysophosphatidic acid binds to and activates GPR92, a G protein-coupled receptor highly expressed in gastrointestinal lymphocytes. J Pharmacol Exp Ther 318:619-628.

Lee CW, Rivera R, Dubin AE, and Chun J (2007) LPA(4)/GPR23 is a lysophosphatidic acid (LPA) receptor utilizing $\mathrm{G}(\mathrm{s})$-, G(q)/G(i)-mediated calcium signaling and G(12/13)-mediated Rho activation. J Biol Chem 282:4310-4317.

Lee CW, Rivera R, Gardell S, Dubin AE, and Chun J (2006) GPR92 as a new G12/13and Gq-coupled lysophosphatidic acid receptor that increases cAMP, $\mathrm{LPA}_{5}$. J Biol Chem 281:23589-23597.

Lee M, Choi S, Halldén G, Yo SJ, Schichnes D, and Aponte GW (2009) P2Y5 is a G(alpha)i, G(alpha)12/13 G protein-coupled receptor activated by lysophosphatidic acid that reduces intestinal cell adhesion. Am J Physiol Gastrointest Liver Physiol 297:G641-G654.

Lee MJ, Thangada S, Claffey KP, Ancellin N, Liu CH, Kluk M, Volpi M, Sha'afi RI, and Hla T (1999) Vascular endothelial cell adherens junction assembly and morphogenesis induced by sphingosine-1-phosphate. Cell 99:301-312.

Lee MJ, Thangada S, Paik JH, Sapkota GP, Ancellin N, Chae SS, Wu M, MoralesRuiz M, Sessa WC, Alessi DR, et al. (2001) Akt-mediated phosphorylation of the G protein-coupled receptor EDG-1 is required for endothelial cell chemotaxis. Mol Cell 8:693-704.

Lee MJ, Van Brocklyn JR, Thangada S, Liu CH, Hand AR, Menzeleev R, Spiegel S, and Hla T (1998) Sphingosine-1-phosphate as a ligand for the G protein-coupled receptor EDG-1. Science 279:1552-1555.

Lee S, Jeong J, Majewski T, Scherer SE, Kim MS, Tuziak T, Tang KS, Baggerly K, Grossman HB, Zhou JH, et al. (2007) Forerunner genes contiguous to RB1 contribute to the development of in situ neoplasia. Proc Natl Acad Sci USA 104: 13732-13737.

Lee Z, Cheng CT, Zhang H, Subler MA, Wu J, Mukherjee A, Windle JJ, Chen CK, and Fang X (2008) Role of $\mathrm{LPA}_{4} / \mathrm{p} 2 \mathrm{y} 9 /$ GPR23 in negative regulation of cell motility. Mol Biol Cell 19:5435-5445.

Levkau B, Hermann S, Theilmeier G, van der Giet M, Chun J, Schober O, and Schäfers M (2004) High-density lipoprotein stimulates myocardial perfusion in vivo. Circulation 110:3355-3359.

Li Z, Chen W, Hale JJ, Lynch CL, Mills SG, Hajdu R, Keohane CA, Rosenbach MJ, Milligan JA, Shei GJ, Chrebet G, Parent SA, Bergstrom J, Card D, Forrest M, Quackenbush EJ, Wickham LA, Vargas H, Evans RM, Rosen H, and Mandala S. Chen, J.J. Hale, C.L. Lynch, S.G. Mills, et al (2005) Discovery of potent 3,5diphenyl-1,2,3-oxadiazole sphingoisne-1-phosphate-1 $\left(\mathrm{S}_{1} \mathrm{P}_{1}\right)$ receptor agonists with exceptional selectivity against $\mathrm{S}_{1} \mathrm{P}_{2}$ and $\mathrm{S}_{1} \mathrm{P}_{3}$. J Med Chem 48:6169-6173.

Lin S, Wang D, Iyer S, Ghaleb AM, Shim H, Yang VW, Chun J, and Yun CC (2009) The absence of LPA2 attenuates tumor formation in an experimental model of colitis-associated cancer. Gastroenterology 136:1711-1720.

Liu Y, Wada R, Yamashita T, Mi Y, Deng CX, Hobson JP, Rosenfeldt HM, Nava VE, Chae SS, Lee MJ, et al. (2000) Edg-1, the G protein-coupled receptor for sphingosine-1-phosphate, is essential for vascular maturation. J Clin Invest 106:951961.

Matas-Rico E, García-Diaz B, Llebrez-Zayas P, López-Barroso D, Santín L, Pedraza C, Smith-Fernández A, Fernández-Llebrez P, Tellez T, Redondo M, et al. (2008) Deletion of lysophosphatidic acid receptor LPA1 reduces neurogenesis in the mouse dentate gyrus. Mol Cell Neurosci 39:342-355.

Maceyka M, Milstien S, and Spiegel S (2009) Sphingosine-1-phosphate: the Swiss army knife of sphingolipid signaling. J Lipid Res $\mathbf{5 0}$ (Suppl):S272-S276.

MacLennan AJ, Benner SJ, Andringa A, Chaves AH, Rosing JL, Vesey R, Karpman AM, Cronier SA, Lee N, Erway LC, et al. (2006) The $\mathrm{S}_{1} \mathrm{P}_{2}$ sphingosine 1-phosphate receptor is essential for auditory and vestibular function. Hear Res 220:38-48.

Means CK, Xiao CY, Li Z, Zhang T, Omens JH, Ishii I, Chun J, and Brown JH (2007) Sphingosine 1-phosphate S1P2 and S1P3 receptor-mediated Akt activation protects against in vivo myocardial ischemia-reperfusion injury. Am J Physiol Heart Circ Physiol 292:H2944-H2951.

Malek RL, Toman RE, Edsall LC, Wong S, Chiu J, Letterle CA, Van Brocklyn JR, Milstien S, Spiegel S, and Lee NH (2001) Nrg-1 belongs to the endothelial differentiation gene family of $\mathrm{G}$ protein-coupled sphingosine-1-phosphate receptors. J Biol Chem 276:5692-5699.

Mandala S, Hajdu R, Bergstrom J, Quackenbush E, Xie J, Milligan J, Thornton R, Shei GJ, Card D, Keohane C, et al. (2002) Alteration of lymphocyte trafficking by sphingosine-1-phosphate receptor agonists. Science 296:346-349.

McIntyre TM, Pontsler AV, Silva AR, St Hilaire A, Xu Y, Hinshaw JC, Zimmerman GA, Hama K, Aoki J, Arai H, et al. (2003) Identification of an intracellular receptor for lysophosphatidic acid (LPA): LPA is a transcellular PPARgamma agonist. Proc Natl Acad Sci USA 100:131-136.

Mills GB and Moolenaar WH (2003) The emerging role of lysophosphatidic acid in cancer. Nat Rev Cancer 3:582-591.

Mizugishi K, Yamashita T, Olivera A, Miller GF, Spiegel S, and Proia RL (2005) Essential role for sphingosine kinases in neural and vascular development. Mol Cell Biol 25:11113-11121.

Moolenaar WH, van Meeteren LA, and Giepmans BN (2004) The ins and outs of lysophosphatidic acid signaling. Bioessays 26:870-881.

Murakami M, Shiraishi A, Tabata K, and Fujita N (2008) Identification of the orphan GPCR, P2Y(10) receptor as the sphingosine-1-phosphate and lysophosphatidic acid receptor. Biochem Biophys Res Commun 371:707-712.

Mutoh T and Chun J (2008) Lysophospholipid activation of G protein-coupled receptors. Subcell Biochem 49:269-297.

Niessen F, Schaffner F, Furlan-Freguia C, Pawlinski R, Bhattacharjee G, Chun J, Derian CK, Andrade-Gordon P, Rosen H, and Ruf W (2008) Dendritic cell PAR1$\mathrm{S}_{1} \mathrm{P}_{3}$ signalling couples coagulation and inflammation. Nature 452:654-658.

Nofer JR, van der Giet M, Tölle M, Wolinska I, von Wnuck Lipinski K, Baba HA, Tietge UJ, Gödecke A, Ishii I, Kleuser B, et al. (2004) HDL induces NO-dependent vasorelaxation via the lysophospholipid receptor $\mathrm{S}_{1} \mathrm{P}_{3}$. J Clin Invest 113:569-581.
Noguchi K, Herr D, Mutoh T, and Chun J (2009) Lysophosphatidic acid (LPA) and its receptors. Curr Opin Pharmacol 9:15-23.

Noguchi K, Ishii S, and Shimizu T (2003) Identification of p2y9/GPR23 as a novel G protein-coupled receptor for lysophosphatidic acid, structurally distant from the Edg family. $J$ Biol Chem 278:25600-25606.

O’Dowd BF, Nguyen T, Jung BP, Marchese A, Cheng R, Heng HH, Kolakowski LF Jr, Lynch KR, and George SR (1997) Cloning and chromosomal mapping of four putative novel human G-protein-coupled receptor genes. Gene 187:75-81.

Oh DY, Yoon JM, Moon MJ, Hwang JI, Choe H, Lee JY, Kim JI, Kim S, Rhim H, O'Dell DK, et al. (2008) Identification of farnesyl pyrophosphate and $N$ arachidonylglycine as endogenous ligands for GPR92. J Biol Chem 283:2105421064.

Ohta H, Sato K, Murata N, Damirin A, Malchinkhuu E, Kon J, Kimura T, Tobo M, Yamazaki Y, Watanabe T, et al. (2003) Ki16425, a subtype-selective antagonist for EDG-family lysophosphatidic acid receptors. Mol Pharmacol 64:994-1005.

Oka S, Ota R, Shima M, Yamashita A, and Sugiura T (2010) GPR35 is a novel lysophosphatidic acid receptor. Biochem Biophys Res Commun 395:232-237.

Okamoto H, Takuwa N, Yokomizo T, Sugimoto N, Sakurada S, Shigematsu H, and Takuwa Y (2000) Inhibitory regulation of Rac activation, membrane ruffling, and cell migration by the $\mathrm{G}$ protein-coupled sphingosine-1-phosphate receptor EDG5 but not EDG1 or EDG3. Mol Cell Biol 20:9247-9261.

Okusa MD, Ye H, Huang L, Sigismund L, Macdonald T, and Lynch KR (2003) Selective blockade of lysophosphatidic acid $\mathrm{LPA}_{3}$ receptors reduces murine renal ischemia-reperfusion injury. Am J Physiol Renal Physiol 285:F565-F574.

Osada M, Yatomi Y, Ohmori T, Ikeda H, and Ozaki Y (2002) Enhancement of sphingosine 1-phosphate-induced migration of vascular endothelial cells and smooth muscle cells by an EDG-5 antagonist. Biochem Biophys Res Commun 299:483-487.

Pasternack SM, von Kügelgen I, Aboud KA, Lee YA, Rüschendorf F, Voss K, Hillmer AM, Molderings GJ, Franz T, Ramirez A, et al. (2008) G protein-coupled receptor P2Y5 and its ligand LPA are involved in maintenance of human hair growth. Nat Genet 40:329-334.

Pradère JP, Klein J, Grès S, Guigné C, Neau E, Valet P, Calise D, Chun J, Bascands JL, Saulnier-Blache JS, et al. (2007) $\mathrm{LPA}_{1}$ receptor activation promotes renal interstitial fibrosis. J Am Soc Nephrol 18:3110-3118.

Rivera J, Proia RL, and Olivera A (2008) The alliance of sphingosine-1-phosphate and its receptors in immunity. Nat Rev Immunol 8:753-763.

Rivera R and Chun J (2008) Biological effects of lysophospholipids. Rev Physiol Biochem Pharmacol 160:25-46.

Rubenfeld J, Guo J, Sookrung N, Chen R, Chaicumpa W, Casolaro V, Zhao Y, Natarajan V, and Georas S (2006) Lysophosphatidic acid enhances interleukin-13 gene expression and promoter activity in T cells. Am J Physiol Lung Cell Mol Physiol 290:L66-L74.

Saba JD (2004) Lysophospholipids in development: Miles apart and edging in. J Cell Biochem 92:967-992.

Sanchez T, Skoura A, Wu MT, Casserly B, Harrington EO, and Hla T (2007) Induction of vascular permeability by the sphingosine-1-phosphate receptor-2 (S1P2R) and its downstream effectors ROCK and PTEN. Arterioscler Thromb Vasc Biol 27:1312-1318.

Sanna MG, Liao J, Jo E, Alfonso C, Ahn MY, Peterson MS, Webb B, Lefebvre S, Chun J, Gray N, et al. (2004) Sphingosine 1-phosphate (S1P) receptor subtypes $\mathrm{S}_{1} \mathrm{P}_{1}$ and $\mathrm{S}_{1} \mathrm{P}_{3}$, respectively, regulate lymphocyte recirculation and heart rate. J Biol Chem 279:13839-13848.

Sanna MG, Wang SK, Gonzalez-Cabrera PJ, Don A, Marsolais D, Matheu MP, Wei SH, Parker I, Jo E, Cheng WC, et al. (2006) Enhancement of capillary leakage and restoration of lymphocyte egress by a chiral S1P1 antagonist in vivo. Nat Chem Biol 2:434-441.

Santin LJ, Bilbao A, Pedraza C, Matas-Rico E, López-Barroso D, Castilla-Ortega E, Sánchez-López J, Riquelme R, Varela-Nieto I, de la Villa P, et al. (2009) Behavioral phenotype of maLPA1-null mice: increased anxiety-like behavior and spatial memory deficits. Genes Brain Behav 8:772-784.

Schwab SR and Cyster JG (2007) Finding a way out: lymphocyte egress from lymphoid organs. Nat Immunol 8:1295-1301.

Serriere-Lanneau V, Teixeira-Clerc F, Li L, Schippers M, de Wries W, Julien B, Tran-Van-Nhieu J, Manin S, Poelstra K, Chun J, et al. (2007) The sphingosine 1-phosphate receptor $\mathrm{S}_{2} \mathrm{P}_{2}$ triggers hepatic wound healing. FASEB J 21:20052013.

Shimizu H, Takahashi M, Kaneko T, Murakami T, Hakamata Y, Kudou S, Kishi T, Fukuchi K, Iwanami S, Kuriyama K, et al. (2005) KRP-203, a novel synthetic immunosuppressant, prolongs graft survival and atenuates chronic rejection in rat skin and heart allografts. Circulation 111:222-229.

Shinkuma S, Akiyama M, Inoue A, Aoki J, Natsuga K, Nomura T, Arita K, Abe R, Ito K, Nakamura H, et al. (2010) Prevalent LIPH founder mutations lead to loss of P2Y5 activation ability of PA-PLA1alpha in autosomal recessive hypotrichosis. Hum Mutat 31:602-610.

Simon MF, Daviaud D, Pradère JP, Grès S, Guigné C, Wabitsch M, Chun J, Valet P, and Saulnier-Blache JS (2005) Lysophosphatidic acid inhibits adipocyte differentiation via lysophosphatidic acid 1 receptor-dependent down-regulation of peroxisome proliferator-activated receptor gamma2. J Biol Chem 280:14656-14662.

Skoura A and Hla T (2009) Lysophospholipid receptors in vertebrate development, physiology, and pathology. J Lipid Res 50 (Suppl):S293-S298.

Skoura A, Sanchez T, Claffey K, Mandala SM, Proia RL, and Hla T (2007) Essential role of sphingosine 1-phosphate receptor 2 in pathological angiogenesis of the mouse retina. J Clin Invest 117:2506-2516.

Sonoda H, Aoki J, Hiramatsu T, Ishida M, Bandoh K, Nagai Y, Taguchi R, Inoue K and Arai H (2002) A novel phosphatidic acid-selective phospholipase A1 that produces lysophosphatidic acid. J Biol Chem 277:34254-34263.

Sumida H, Noguchi K, Kihara Y, Abe M, Yanagida K, Hamano F, Sato S, Tamaki K, Morishita Y, Kano MR, et al. (2010) $\mathrm{LPA}_{4}$ regulates blood and lymphatic vessel formation during mouse embryogenesis. Blood doi:10.1182/blood-2010-03-272443 Tabata K, Baba K, Shiraishi A, Ito M, and Fujita N (2007) The orphan GPCR GPR87 
was deorphanized and shown to be a lysophosphatidic acid receptor. Biochem Biophys Res Commun 363:861-866.

Tager AM, LaCamera P, Shea BS, Campanella GS, Selman M, Zhao Z, Polosukhin V, Wain J, Karimi-Shah BA, Kim ND, et al. (2008) The lysophosphatidic acid receptor LPA1 links pulmonary fibrosis to lung injury by mediating fibroblast recruitment and vascular leak. Nat Med 14:45-54.

Takuwa N, Ohkura S, Takashima S, Ohtani K, Okamoto Y, Tanaka T, Hirano K, Usui S, Wang F, Du W, et al. (2009) $\mathrm{S}_{1} \mathrm{P}_{3}$-mediated cardiac fibrosis in sphingosine kinase 1 transgenic mice involves reactive oxygen species. Cardiovasc Res 85:484493.

Teo ST, Yung YC, Herr DR, and Chun J (2009) Lysophosphatidic acid in vascular development and disease. IUBMB Life 61:791-799.

Theilmeier G, Schmidt C, Herrmann J, Keul P, Schäfers M, Herrgott I, Mersmann J, Larmann J, Hermann S, Stypmann J, et al. (2006) High-density lipoproteins and their constituent, sphingosine-1-phosphate, directly protect the heart against ischemia/reperfusion injury in vivo via the S1P3 lysophospholipid receptor. Circulation 114:1403-1409.

Trimbuch T, Beed P, Vogt J, Schuchmann S, Maier N, Kintscher M, Breustedt J, Schuelke M, Streu N, Kieselmann O, et al. (2009) Synaptic PRG-1 modulates excitatory transmission via lipid phosphate-mediated signaling. Cell 138:12221235.

Van Brocklyn JR, Gräler MH, Bernhardt G, Hobson JP, Lipp M, and Spiegel S (2000) Sphingosine-1-phosphate is a ligand for the G protein-coupled receptor EDG-6. Blood 95:2624-2629.

Van Brocklyn JR, Tu Z, Edsall LC, Schmidt RR, and Spiegel S (1999) Sphingosine 1-phosphate-induced cell rounding and neurite retraction are mediated by the $G$ protein-coupled receptor H218. J Biol Chem 274:4626-4632.

Virag T, Elrod DB, Liliom K, Sardar VM, Parrill AL, Yokoyama K, Durgam G, Deng W, Miller DD, and Tigyi G (2003) Fatty alcohol phosphates are subtype-selective agonists and antagonists of lysophosphatidic acid receptors. Mol Pharmacol 63: 1032-1042.

Walter DH, Rochwalsky U, Reinhold J, Seeger F, Aicher A, Urbich C, Spyridopoulos I, Chun J, Brinkmann V, Keul P, et al. (2007) Sphingosine-1-phosphate stimulates the functional capacity of progenitor cells by activation of the CXCR4-dependent signaling pathway via the S1P3 receptor. Arterioscler Thromb Vasc Biol 27:275282 .

Walzer T, Chiossone L, Chaix J, Calver A, Carozzo C, Garrigue-Antar L, Jacques Y, Baratin M, Tomasello E, and Vivier E (2007) Natural killer cell trafficking in vivo requires a dedicated sphingosine 1-phosphate receptor. Nat Immunol 8:13371344.

Wang W, Graeler MH, and Goetzl EJ (2005) Type 4 sphingosine 1-phosphate G protein-coupled receptor (S1P4) transduces S1P effects on T cell proliferation and cytokine secretion without signaling migration. FASEB J 19:1731-1733.

Williams JR, Khandoga AL, Goyal P, Fells JI, Perygin DH, Siess W, Parrill AL, Tigyi

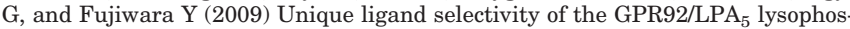
phatidate receptor indicates role in human platelet activation. $J$ Biol Chem 284: 17304-17319.

Windh RT, Lee MJ, Hla T, An S, Barr AJ, and Manning DR (1999) Differential coupling of the sphingosine 1-phosphate receptors Edg-1, Edg-3, and H218/Edg-5 to the G(i), G(q), and G(12) families of heterotrimeric G proteins. J Biol Chem 274:27351-27358.

Witte ON, Kabarowski JH, Xu Y, Le LQ, and Zhu K (2005) Retraction. Science 307:206.

Xu Y, Zhu K, Hong G, Wu W, Baudhuin LM, Xiao Y, and Damron DS (2000) Sphingosylphosphorylcholine is a ligand for ovarian cancer G-protein-coupled receptor 1 [published erratum appears in Nat Cell Biol 2:E146, 2000; retraction appears in Nat Cell Biol 8:299, 2006]. Nat Cell Biol 2:261-267.

Xu Y, Zhu K, Hong G, Wu W, Baudhuin LM, Xiao Y, Damron DS (2006) Retraction. Sphingosylphosphorylcholine is a ligand for ovarian cancer G-protein-coupled receptor 1. Nat Cell Biol 8:299.

Yanagida K, Masago K, Nakanishi H, Kihara Y, Hamano F, Tajima Y, Taguchi R, Shimizu T, and Ishii S (2009) Identification and characterization of a novel lysophosphatidic acid receptor, p2y5/LPA6. J Biol Chem 284:17731-17741.

Ye X, Hama K, Contos JJ, Anliker B, Inoue A, Skinner MK, Suzuki H, Amano T, Kennedy G, Arai H, et al. (2005) LPA3-mediated lysophosphatidic acid signalling in embryo implantation and spacing. Nature 435:104-108.

Ye X, Skinner MK, Kennedy G, and Chun J (2008) Age-dependent loss of sperm production in mice via impaired lysophosphatidic acid signaling. Biol Reprod 79:328-336.

Yea K, Kim J, Lim S, Park HS, Park KS, Suh PG, and Ryu SH (2008) Lysophosphatidic acid regulates blood glucose by stimulating myotube and adipocyte glucose uptake. J Mol Med 86:211-220.

Yin H, Chu A, Li W, Wang B, Shelton F, Otero F, Nguyen DG, Caldwell JS, and Chen YA (2009) Lipid G protein-coupled receptor ligand identification using betaarrestin PathHunter assay. J Biol Chem 284:12328-12338.

Zhao Y, Tong J, He D, Pendyala S, Evgeny B, Chun J, Sperling AI, and Natarajan V (2009) Role of lysophosphatidic acid receptor $\mathrm{LPA}_{2}$ in the development of allergic airway inflammation in a murine model of asthma. Respir Res 10:114.

Zhu R, Snyder AH, Kharel Y, Schaffter L, Sun Q, Kennedy PC, Lynch KR, and Macdonald TL (2007) Asymmetric synthesis of conformationally constrained fingolimod analogues-discovery of an orally active sphingosine 1-phosphate receptor type-1 agonist and receptor type-3 antagonist. J Med Chem 50:6428-6435. 